\title{
The Profit Split Method: Status Quo and Outlook in Light of the BEPS Action Plan
}

\begin{abstract}
The authors analyse whether the OECD's base erosion and profit shifting (BEPS) project would increase the use of the profit split method. After reviewing the current landscape in this context, the authors focus on situations in which the profit split method applies, the various approaches that can be used to split the profit among associated enterprises and reasons why the profit split method has been infrequently applied. Finally, the authors present their views on the application of the profit split method in light of the BEPS Action Plan.
\end{abstract}

\section{Introduction}

This article will comment on whether the OECD's base erosion and profit shifting (BEPS) project would increase the use of the profit split method. First, a summary is presented of the status quo with regard to the profit split method, wherein the focus of the discussion will be on situations in which the profit split method applies, the various approaches that can be used to split the profits among associated enterprises and the reasons why the profit split method has been infrequently applied. The authors will also present their outlook on the application of the profit split method in light of the BEPS Action Plan, ${ }^{1}$ in particular Action 13 on re-examining transfer pricing documentation, which has resulted in the release of an OECD report on country-by-country reporting. ${ }^{2}$ The authors conclude that two-sided methods will be applied more frequently and that the country-by-country template would serve as a useful starting point to ascertain whether a profit split method should be undertaken.

\section{Background}

The profit split method is one of the transactional profit methods and the only two-sided method provided by the OECD Transfer Pricing Guidelines for Multinational Enterprises and Tax Administrations (OECD Guidelines). ${ }^{3}$ This method aims at splitting the combined profits (or losses) arising from controlled transactions between as-

\footnotetext{
Vikram Chand is Academic Coordinator, Masters of Advanced Studies in International Taxation, at the University of Lausanne, Switzerland. The author can be contacted at vikram.chand@unil.ch. Sagar Wagh is international tax and transfer pricing specialist, based in Mumbai, India. The author can be contacted at sagarwagh@gmail.com.

1. OECD, Action Plan on Base Erosion and Profit Shifting (OECD 2013), International Organizations' Documentation IBFD.

2. OECD, Guidance on Transfer Pricing Documentation and Country-by Country Reporting (OECD 16 Sept. 2014).

3. OECD, Transfer Pricing Guidelines for Multinational Enterprises and Tax Administrations (OECD Guidelines) (OECD 22 July 2010), International Organizations' Documentation IBFD.
}

sociated enterprises on an economically valid basis, that approximates the division of profits that would have been anticipated and reflected in an agreement made at arm's length. ${ }^{4}$ It is important that the profit split method not be confused with the non-arm's length approach of profit allocation, namely the global formulary apportionment method. This is because, when applying the profit split method, the division of profits arising from the controlled transactions between associated enterprises is based on a scientific analysis, while in case of the non-arm's length approaches, the division of profits arising from a controlled transaction is based on a pre-determined formula. ${ }^{5}$

The application of the profit split method has evolved over a period of time at the OECD level. ${ }^{6}$ Historically, the 1979 OECD Guidelines excluded the profit split method as an acceptable transfer pricing method. ${ }^{7}$ Nonetheless, in 1994, the OECD published a discussion draft on transfer pricing that considered profit-based methods, in particular, the profit split method. ${ }^{8}$ Based on the draft, in the 1995 update to the OECD Guidelines, the profit split method was finally included as one of the prescribed methods ${ }^{9}$ that could be applied where the traditional transaction methods were found to be inapplicable. ${ }^{10}$ Subsequently, in light of the OECD's work on updating the transfer pricing

4. Para. 2.108 OECD Guidelines (2010).

5. Paras. 1.16-1.18 OECD Guidelines (2010). See also R.M. Hammer, Will the Arm's Length Test Stand the Test of Time? The Spectre of Apportionment, 24 Intertax 1 (1996), at 2, 3; J. Owens, Should the Arm's Length Principle Retire?, 12 Intl. Transfer Pricing J. 3 (2005), at 99-101, Journals IBFD.

6. For an historical overview of the profit split method in the United States, see Hammer, supra n. 5, at 4-5.

7. Nevertheless, a reference was made to profit allocations based on a "proportionate contribution to final profit". Para. 72 OECD Guidelines (1979). The quoted phrase has been interpreted as implicitly recognizing the existence of the profit split method.

8. OECD, Transfer Pricing Guidelines for Multinational Enterprises and Tax Administrations: Discussion Draft of Part I: Principles and Methods (OECD 1994). The comments received on the draft reflected the difference of opinion among stakeholders with respect to the acceptability of the profit split method as an arm's length method. The main argument raised by stakeholders was that, in uncontrolled circumstances, apart from partnerships and joint ventures, none of the parties to the transaction calculate combined profit which afterwards is split among them. Thus, the profit split method does not reflect reality. However, it was acknowledged by some stakeholders that the profit split method could serve as an appropriate method to determine the arm's length nature of compensation attributable to the parties in certain transactions. See H. Becker, Comments on Profit Methods Proposed by the OECD Discussion Report, Intertax 5(1995), at 256 .

9. Para. 3.5 OECD Guidelines (1995)

10. Para. 2.49 OECD Guidelines (1995). 
guidelines ${ }^{11}$ specifically chapters I-III, ${ }^{12}$ the OECD Guidelines provide for the selection of the most appropriate method for a particular transaction, rather than emphasizing a hierarchy of methods. This demonstrates a higher level of acceptability of the profit methods (also the profit split method) by OECD member countries. ${ }^{13}$

Recently, in light of the BEPS initiative, ${ }^{14}$ it is anticipated that the profit split method will be applied with increasing frequency by the tax authorities. ${ }^{15}$

\section{Status Quo of the Profit Split Method}

\subsection{Situations in which the profit split method applies}

The OECD Guidelines ${ }^{16}$ state that the profit split method may be applied when the associated enterprises are engaged in highly integrated activities ${ }^{17}$ or when the associated enterprises make unique or valuable contributions (especially in the form of unique intangibles) ${ }^{18}$ to the transactions. In such cases, the use of the profit split method is appropriate, as independent parties could wish to share the profits in proportion to their respective contributions. Thus, the profit split method is applicable in a situation where the functional analysis indicates that the parties involved in the transaction undertake functions that are more inclined toward being classified as non-routine activities as opposed to routine activities. ${ }^{19}$

\subsection{Approaches to splitting the profit}

\subsubsection{Introductory remarks}

The combined profit to be split when applying the profit split method is the net operating profit. However, in certain cases where it is difficult to allocate indirect expenses incurred by parties to the controlled transaction

11. On 28 February 2006 , as part of its procedures for monitoring the implementation of the 1995 OECD Guidelines, the OECD invited public comments on the application of the transactional profit methods. The various comments received were published on 6 September 2006. Based on these comments, a discussion draft was released. See OECD, Transactional Profit Methods: Discussion Draft for Public Comment (OECD 25 Jan. 2008), International Organizations' Documentation IBFD. The public comments on this draft were received by 7 May 2008. Finally, on 19 November 2008 , the OECD held a public consultation to discuss the profit methods and other issues.

12. OECD, Proposed Revision of Chapters I-III of the Transfer Pricing Guidelines (OECD 9 Sept. 2009), International Organizations' Documentation IBFD, at 26-28.

13. Para. 2.2 OECD Guidelines (2010).

14. OECD, Action Plan on Base Erosion and Profit Shifting, supra n. 1

15. See e.g. C.H. Lowell \& M. Herrington, BEPS: Current Reality and Planning in Anticipation, 21 Intl. Transfer Pricing J. 2 (2014), at 69, Journals IBFD; M. Herrington \& C.H. Lowell, The BEPS Project: Planning in Anticipation, 21 Intl. Transfer Pricing J. 3 (2014), at 163, Journals IBFD. The OECD is clear that it does not want to move to a formulary apportionment mechanism. See OECD, Action Plan on Base Erosion and Profit Shifting, supra n. 1 , at 14 .

16. Para. 2.109 OECD Guidelines (2010)

17. See OECD, Ctr. for Tax Policy and Admin., 2010 Report on the Attribution of Profits to Permanent Establishments, (OECD 22 July 2010), sec. C-3, International Organizations' Documentation IBFD (especially regarding the application of the profit split method to integrated trading activities).

18. See Annex II to chap. II OECD Guidelines (2010) (regarding the application of the profit split method to a situation where each associated enterprise makes unique contributions).

19. M. Milewska \& M. Hurtado de Mendoza, The Increasing Importance of Intangible Assets and the Rise of Profit Split Methods, 17 Intl. Transfer Pricing J. 2 (2010), at 162, Journals IBFD. at hand, it may be appropriate to carry out a split of gross profit. ${ }^{20}$

The profit split method can be applied for both ex ante (price setting) as well as ex post (outcome testing) transfer pricing analysis. The ex ante analysis is aimed at deciding the mechanism of splitting profits arising from a controlled transaction before such a transaction actually takes place. ${ }^{21}$ This profit split mechanism is designed in such a way that the division of profits among associated enterprises adheres to the arm's length standard. The ex post analysis is conducted after the transaction takes place and tests whether the split of profit arising from a particular controlled transaction among associated enterprises is at arm's length. ${ }^{22}$

With respect to the division of profit, the OECD Guidelines suggest two approaches, namely the contribution analysis and residual analysis, by acknowledging that such approaches are neither exhaustive nor mutually exclusive. ${ }^{23}$ Under a contribution analysis, the total profit arising from a controlled transaction is divided among the associated enterprises based upon a reasonable approximation of profit division that independent enterprises would have expected to realize from engaging in comparable transactions (comparable profit split). ${ }^{24}$ If comparables do not exist, the contribution analysis should be based on a detailed analysis of functions performed, assets used and risks assumed, and the variables used to divide combined profit among participants should be economically justified. ${ }^{25}$ Thus, the method can be applied even when a comparable does not exist (contribution profit split).

On the other hand, a residual analysis (residual profit split) aims at dividing the total profit arising from a controlled transaction among associated enterprises in two stages. In the first stage, each participant is allocated an arm's length remuneration for its routine contributions by applying one of the traditional methods or the transaction net margin method (TNMM) by reference to the remuneration of comparable transactions between independent enterprises. In the second stage, any residual profit (or loss), is allocated among the parties based on the relative contribution of each party to the transaction under consideration. ${ }^{26}$

Either type of profit split requires a fundamental analysis of the relative contributions of the associated enterprises generating the profit. The crucial question concerns how to translate the relative contributions in a ratio for split-

20. Para. 2.131 OECD Guidelines (2010)

21. Para. 2.127 OECD Guidelines (2010)

22. Para. 3.70 OECD Guidelines (2010).

23. Para. 2.118 OECD Guidelines (2010). See also United Nations, Practical Manual on Transfer Pricing for Developing Countries (2013), para. 6.3.14.

24. Para. 2.119 OECD Guidelines (2010). This approach is similar to the com parable profit split method under the US transfer pricing regulations.

25. See e.g. IN: ITAT, 31 Dec. 2013, ITO v. Net Freight (India) Pvt. Ltd., Delhi ITAT,TS-363-ITAT-2013-TP(DEL)-TP, Tax Treaty Case Law IBFD. In this case, the Tribunal held that profit may be split based on the relative contribution of the associated enterprises, which need not be benchmarked by external markets or comparable data. Nevertheless, a scientific methodology may be applied to allocate the profit among associated enterprises to the transaction.

26. Para. 2.121 OECD Guidelines (2010) 
ting the profit. ${ }^{27}$ The following methods are mainly used in this regard.

\subsubsection{External market data}

Independent parties in certain sectors may base the split of profit on external market data available in the public domain, such as joint-venture arrangements (e.g. development projects in the oil and gas industry or arrangements between independent music record labels and music artists).$^{28}$ However, in practice, such a method is not easy to apply, as reliable external market data necessary to split the combined profit between the associated enterprises are often not available. ${ }^{29}$

\subsubsection{Internal data: The use of allocation keys}

In absence of sufficient comparable transactions for undertaking a split of profit, the OECD Guidelines prescribe the use of internal data from the taxpayer's own cost accounting or financial records. ${ }^{30}$ Such data can be useful for applying allocation keys to split the profit. ${ }^{31}$

Various allocation keys can be used depending on the industry, the transactions and the value drivers involved. ${ }^{32}$ Broadly, allocation keys can be divided into asset- or capital-based or cost-based keys. ${ }^{33}$ Asset- or capital-based keys are, in particular, useful when a strong correlation exists between the capital employed and the tangible or intangible asset which creates value. ${ }^{34}$ For example, it is appropriate to use this key when (i) the associated enterprises contribute unique intangibles and (ii) the relative value of each associated enterprise's contribution of intangible property (IP) is determined on the capitalized cost of developing the intangibles and all related improvements and updates as reduced by an appropriate amount of amortization based on the useful life of each intangible. ${ }^{35}$ On the other hand, cost-based keys can be utilized where a strong correlation exists between relative expenses incurred and the relative value added. For example, marketing expenses may be an appropriate key for distributors-marketers if advertising generates material marketing intangibles ${ }^{36}$ Further, even compensation/labour costs can be used where the eco-

27. S. Pantelidaki, P. Oparah \& A. Hickman, CUPs and Profit Split: When and How to Use, Transfer Pricing Intl. J. (Dec. 2011), at 3; S. Gonnet \& P. Fris, Contribution Analysis under the Profit Split Method, 6 Intl. Tax Rev. 11 (2007), at 8 , available at http://www.nera.com/content/dam/nera/publications/archive1/PUB_ContributionAnalyses_ITR_Dec2007.pdf

28. Para. 2.133 OECD Guidelines (2010).

29. Para. 6.3.15.2, UN Practical Manual on Transfer Pricing for Developing Countries (2013).

30. Para. 2.141 OECD Guidelines (2010).

31. Para. 2.142-2.144 OECD Guidelines (2010).

32. See Pantelidaki, Oparah \& Hickman, supra n. 27, at 3 .

33. Para. 2.135 OECD Guidelines (2010).

34. Para. 2.136 OECD Guidelines (2010).

35. Para. 2.137 OECD Guidelines (2010). For an explanation of this approach vis-à-vis intangible property development, see Gonnet \& Fris, supran. 27, at 9-10; para. 6.3.14.6, UN Practical Manual on Transfer Pricing for Developing Countries (2013). It is suggested that this approach be utilized in industries that require constant investments in intangibles (e.g. the automotive and electronics industries). See Milewska \& Hurtado de Mendoza, supra $\mathrm{n} .19$, at 163 .

36. Para. 2.138 OECD Guidelines (2010) nomic value is created by key individual employees ${ }^{37}$ For example, combined profit resulting from global trading activities, can reliably be split based on the bonuses of the traders that generate the profit. ${ }^{38}$

\subsubsection{Bargaining theory models}

Bargaining theory can provide insight to determine the contribution of each associated enterprise to the transaction. In fact, the OECD Guidelines state that associated enterprises could copy the outcome of bargaining between independent enterprises on the free market to determine the profit split. Two stages are envisaged. In the first stage, the initial remuneration to each participant would be commensurate with the lowest price an independent seller would accept and the highest price that the buyer would be reasonably willing to pay. The difference between these two figures would represent the residual profit over which independent enterprises would bargain. In the second stage, this residual profit would be divided based on an analysis of any factors relevant to the associated enterprises that would indicate how independent enterprises might have split the difference between the seller's minimum price and the buyer's maximum price. ${ }^{39}$

While the OECD approach seems theoretical, in practice the game theory could be applied to determine the contribution of the associated enterprises by calculating the Shapley value of the game..$^{40}$ The Shapley value describes a reasonable or fair way to divide gains from cooperation between parties on the basis of the parties' relative contributions. When using Shapley value, the contribution of the players is assessed in relation to the incremental gain that each player brings to any coalitions and sub-coalitions. This mean that the analysis aims at computing, by undertaking various permutations and combinations, the additional profit contributed by each party to the coalition of all the entities to the transaction by virtue of its own contributions. Such additional profit is the difference between (i) the profit generated by the coalition when a particular entity is a participant in the controlled transaction and (ii) the profit generated by the coalition in the absence of such entity. ${ }^{41}$

\subsubsection{Discounted cash flow analysis}

The splitting of profit, especially when undertaking an ex ante analysis, may be done by taking into account the discounted cash flow to the parties to the controlled transactions over the anticipated life of the business. ${ }^{42}$ Such a sim-

37. The labour cost approach can also be considered to be in line with the authorized OECD approach on attribution of profits to a permanent establishment. See Milewska \& Hurtado de Mendoza, supra n. 19, at 163; Gonnet \& Fris, supra n. 27, at 10-11.

38. A. Vogele, W. Witt \& S. Harshbarger, IP Valuation Puts New Theories into Practice, Intl. Tax Rev. 32, at 42 (Jan. 2007) available at http://www.nera. $\mathrm{com} /$ content/dam/nera/publications/archivel/PUB_IP_Valuation_ITR. pdf.

39. Para. 2.122 OECD Guidelines (2010).

40. Gonnet \& Fris, supra n. 27, at 11-12; Pantelidaki, Oparah \& Hickman, supra n. 27 , at 3 .

41. A. Vogele, S. Gonnet \& B. Gottschling, Transfer Prices Determined by Game Theory: 1 - Underlyings, 10 Transfer Pricing Intl. J. 8 (2008), at 1-3.

42. Para. 2.123 OECD Guidelines (2010). 
ulation may be an effective method for applying the profit split method when a start-up is involved and if all the relevant information (such as investment and sales projections) can be made in a reasonably accurate manner. Further, the analysis can also be applied in cases of transfer of intangibles. ${ }^{43}$ The success of this approach depends on obtaining an arm's length discount rate, which might be difficult to ascertain. Thus, the method must be applied with extreme caution. ${ }^{44}$

\subsubsection{Rules of thumb}

Rules of thumb, which are simple averages across transactions, have been used for splitting profit. Such averages are usually applied in licensor-licensee arrangements with respect to the exploitation of valuable intangibles ${ }^{45}$ For example one of the most commonly used rules is to split profit in a $75 \%-25 \%$ ratio between the licensor and licensee. ${ }^{46}$ However, such an approach cannot be assumed to be an arm's length approach for splitting profit unless the split is backed by an appropriate comparable analysis. ${ }^{47}$

\subsubsection{Survey approach}

When internal or external market data are not available, a survey approach can be applied to gather information that will be used as a basis for the contribution analysis. This approach involves the identification of internal (employees of the associated enterprise) and external experts who will then provide expert opinions with respect to the profit split. Personal interviews are required to collect the information, and statistical tools are needed to convert the opinions into quantifiable results. ${ }^{48}$ In the authors opinion, the drawback of this approach is in finding experts who can express their opinion. Even when found, the reliability of their opinions could be questioned unless it is supported by a detailed analysis.

\subsection{Reasons for infrequent application of the profit split method}

The application of the profit split method has several limitations, even though the method can be considered to be the best method with respect to unique transactions carried out by associated enterprises. Apart from reasons such as the general lack of a well-articulated economic theory or practical experience justifying the application of the method, ${ }^{49}$ one of the most significant grounds for not applying the profit split method is the difficulty encoun-

43. Para. 6.29 OECD Guidelines (2010).

44. Para. 2.123 OECD Guidelines (2010)

45. Milewska \& Mendoza, supra n. 19, at 163.

46. See Pantelidaki, Oparah \& Hickman, supra n. 27, at 3 .

47. M. Fiacadorri, A. Mitra \& R. Plunkett, Licensor-Licensee Profit Split and the Income Approach, Intl. Tax Rev. (December 2012 - online version). Such rules of thumb have been considered as inappropriate profit split mechanisms by tax courts in the United States. See US: TC, 1999, Compaq Computer Corp. v. Commissioner of Internal Revenue, TC Memo 1999-220; US: TC, Bausch \& Lomb v. Commissioner, 92 TC 525 (1989), 2nd Circuit (1991); US: TC, 1 Aug. 1985, Ciba-Geigyv. Commissioner, 85 TC 172, Tax Treaty Case Law IBFD.

48. Gonnet \& Fris, supra n. 27, at 13; Vogele, Witt \& Harshbarger, supra n. 38, at 46 .

49. It has been reported that the profit split method is hardly used in India. See H. Zobalia \& J. Devani, Base Erosion and Profit Shifting Report and Action tered in accessing financial information from foreign affiliates. It may be difficult to measure combined revenue and costs for all the associated enterprises participating in the controlled transactions, which would require stating books and records on a common basis and making adjustments for accounting practices and currencies. ${ }^{50}$ Would multinational enterprises be required to work on overcoming such limitations in light of the BEPS Action Plan?

\section{Application of the Profit Split Method in Light of the BEPS Action Plan}

\subsection{Introductory comments}

It has been observed that the current transfer pricing system has led to serious BEPS-related concerns. However, replacing the arm's length principle is not feasible and a better solution is to ensure that transfer pricing outcomes are in line with "value creation". ${ }^{51}$ In fact, in the authors' opinion, the profit split method can be regarded as the best transfer pricing method that can align taxation in accordance with value creation. As stated, the profit split method seeks to evaluate the relative value of the contributions made by the associated enterprises to the transaction. Then the profit is split on the basis of a ratio that is determined based on their respective contributions ${ }^{52}$ (as opposed to a predetermined formula). Such an approach would correspond with the BEPS notion that profit should be taxed where the economic activity driving the profit is performed. ${ }^{53}$

Action Point 8, on transfer pricing aspects of intangibles, has (partly) accomplished this with the release of the discussion draft on the revision of chapter VI of the OECD Guidelines. ${ }^{54}$ The discussion draft clarifies the definition of IP ${ }^{55}$ and aligns taxation of the IP return in accordance with the place where the economic activity actually takes place (as opposed to the jurisdiction in which the IP is legally owned). In essence, the discussion draft, by examining several examples, states that intangible-related returns attributable to an entity in a multinational group depends on the functions performed; assets used or contributed; and risks assumed in the development, enhancement, maintenance or protection of intangibles. ${ }^{56}$ Further, in line with the existing guidance on intangibles, ${ }^{57}$ the dis-

Plan - Overview and Relevance in Indian Context, 20 Asia-Pac. Tax Bull. 1 (2014), at 14, Journals IBFD.

50. Para. 2.114 OECD Guidelines (2010).

51. OECD, Action Plan on Base Erosion and Profit Shifting, supran. 1, at 19-20.

52. A. de Graaf, P. de Haan \& M. de Wilde, Fundamental Change in Countries' Corporate Tax Framework Needed to Properly Address BEPS, 42 Intertax 5 (2014), at 315-316; C. Fuest et al., Profit Shifting and "Aggressive" Tax Planning by Multinational Firms: Issues and Options for Reform, 5 World Tax J. 3 (2013), at 319, Journals IBFD.

53. OECD, Action Plan on Base Erosion and Profit Shifting, supra n. 1, at 11. It could be argued that the global formulary apportionment system could also conform to the BEPS philosophy. However, in the authors' opinion, such an approach would not take into consideration the value created by each entity in the chain.

54. OECD, Revised Discussion Draft on Transfer Pricing Aspects of Intangibles (OECD 30 July 2013)

55. OECD, Revised Discussion Draft on Transfer Pricing Aspects of Intangibles, supra n. 54, paras. 49-64.

56. OECD, Revised Discussion Draft on Transfer Pricing Aspects of Intangibles, supra n. 54 , paras. $65-103$

57. Paras. 6.26-6.27 OECD Guidelines (2010) 
cussion draft suggests the use of the profit split method to transactions that involve unique intangibles. ${ }^{58}$ This approach has been confirmed by the recent deliverable of the OECD on Action Point 8.59

Action 9, which deals with risks and capital, seeks to ensure that inappropriate returns do not accrue to an entity solely because it has contractually assumed risks or has provided capital. ${ }^{60}$ In the authors' opinion, if the above Action's analogy is applied, a substantial portion of the income will be allocated to the entity which economically performs the functions and manages the risk of conducting the economic activity. Thus, the profit split method could once again come into play to align returns with value creation.

Action 10, which deals with high-risk transactions, seeks to clarify - among other points - the application of profit splits in the context of global value chains. ${ }^{61}$ In the authors' opinion, such an application would involve analysing the value added by business functions within a multinational enterprise to ascertain the value added by the members of the multinational group. ${ }^{62}$ The analysis will require an understanding, in addition to a functional analysis, as to how value is created in an enterprise. This would, in turn, require an identification of the key value drivers (critical success factors and risks) of the enterprise with respect to the industry in which it operates. Eventually, such an analysis will serve as a framework for identifying the bargaining positions of the entities involved. If the bargaining power of all entities in a multinational enterprise is high, the application of the profit split method to determine the division of profit among the members of a multinational enterprise seems to be the logical outcome. ${ }^{63}$

While the above Actions clarify the application of the profit split method to specific transactions or situations, Action 13 seeks to enhance transparency in transfer pricing matters by ensuring that multinational enterprises provide all relevant governments with needed information on their global allocation of the income, economic activity and taxes paid among countries according to a common template. ${ }^{64}$ The challenge concerns whether this common template will serve as a tool and guide to applying the profit split method from a practical perspective.

58. OECD, Revised Discussion Draft on Transfer Pricing Aspects of Intangibles, supra n. 54, paras. 166-170.

59. OECD, Guidance on Transfer Pricing Aspects of Intangibles (OECD 16 Sept 2014).

60. OECD, Action Plan on Base Erosion and Profit Shifting, supra n. 1, at 20.

61. OECD, Action Plan on Base Erosion and Profit Shifting, supra n. 1, at 20-21. Transactions in a global value chain could be considered to be "integrated transactions" and thus could warrant application of the profit split method.

62. OECD, Transfer Pricing Comparability Data and Developing Countries (OECD Mar. 2014), para. 25. For the concept of value chain analysis in an integrated multinational, see para. 2.3.5, UN Practical Manual on Transfer Pricing for Developing Countries (2013).

63. Regarding the profit split method and reliance on bargaining power analysis in the context of location savings, see paras. 9.148-9.153 OECD Guidelines (2010). See also S.N. Allen et al., Location Savings: A US Perspective, 11 Intl. Transfer Pricing J. 4 (2004), at 158, Journals IBFD; S. Gonnet, P. Fris \& T. Coriano, Location Specific Advantages: Principles, 6 Transfer Pricing Intl. J. 11 (2011), available at http://www.nera.com/content/dam/nera/ publications/archive2/PUB_TPI_Journal_0611.pdf.

OECD, Action Plan on Base Erosion and Profit Shifting, supra n. 1, at 23.

\subsection{Action Plan 13: Re-examining transfer pricing documentation}

\subsubsection{The country-by-country template ${ }^{65}$}

In July 2013, the OECD released a white paper on transfer pricing documentation. ${ }^{66}$ The white paper, inspired by the EU guidance on transfer pricing documentation, recommended a two-tiered documentation approach ${ }^{67}$ which consists of a master file ${ }^{68}$ and a local file. ${ }^{69}$ Further, the white paper highlighted the possibility that businesses could provide individual country data based on management accounts, consolidated income statements and balance sheets and/or tax returns that would provide tax administrators with a general sense of how their global income is allocated. It is clearly stated that such information would likely not be a sufficient basis for a detailed transfer pricing analysis, but will only serve as a tool for risk assessment purposes. ${ }^{70}$

In October 2013, the OECD published a memorandum on transfer pricing documentation and country-by-country reporting, seeking input on the nature of the information required to be reported in a common template and the mechanisms to be developed for reporting and sharing country-by-country data. ${ }^{71}$ The main purpose of the memorandum was to facilitate the public consultation which was scheduled to be held in early November 2013. ${ }^{72}$ Pursuant to the consultation, in January 2014, the OECD released a discussion draft. ${ }^{73}$ The draft, in addition to a master and local file, provided for a country-bycountry template that consisted of a country-by-country

65. For an overview of the existing provisions on tax disclosure and country-by-country reporting, see M.T. Evers, I. Meier \& C. Spengel, Transparency in Financial Reporting: Is Country-by-Country Reporting Suitable To Combat International Profit Shifting?, 68 Bull. Intl. Taxn. 6/7 (2014), at 298-300, Journals IBFD.

66. OECD, White Paper on Transfer Pricing Documentation (OECD 30 July 2013).

67. OECD, White Paper on Transfer Pricing Documentation, supra n. 66, paras. 74,75 .

68. OECD, White Paper on Transfer Pricing Documentation, supra n. 66, Table 1: Coordinated Documentation Approach - Master file, at 23-24. For example, the master file would provide high-level information about the multinational group's organizational structure, description of business, intangible assets and intercompany financial activities.

69. OECD, White Paper on Transfer Pricing Documentation, supra n. 66, Table 2: Coordinated Documentation Approach - Local file, at 25. The local file focuses on reporting information relevant to the transfer pricing analysis related to transactions taking place between a local country affiliate and associated enterprises in different countries and which are material in the context of the local country's tax system.

70. OECD, White Paper on Transfer Pricing Documentation, supra n. 66, para 72. An example provided to demonstrate the usefulness of disclosing such country data involves a company based in a high-tax jurisdiction reporting $85 \%$ of its income in a low-tax jurisdiction while maintaining $80 \%$ of its employees and assets in a high-tax jurisdiction. In such cases, tax authorities in high-tax jurisdictions could question the genuineness of the arrangement by asking why a substantial portion of the company's income is reported in the low-tax jurisdiction and not in the jurisdiction where the assets and employees are located.

71. OECD, Memorandum on Transfer Pricing Documentation and Country by Country Reporting (OECD 13 Oct. 2013).

72. During the public consultation, the stakeholders, among other points, echoed that the OECD should make it clear that country-by-country information should be used only for initial risk assessment purposes and not as a basis for detailed transfer pricing analysis.

73. OECD, Discussion Draft on Transfer Pricing Documentation and CbC Reporting (30 Jan. 2014), International Organizations' Documentation IBFD. 
reporting of the multinational group's revenue; earnings before taxes; cash basis income tax paid to the country of organization; cash basis income tax paid to all other countries; total withholding taxes paid; stated capital and accumulated earnings; number of employees; total employee expense; book value of tangible assets other than cash and cash equivalents; and intercompany receipts and payments with respect to royalties, interest and service fees. ${ }^{74}$ The draft template provided for reporting of entity-by-entity information, rather than country-by-country information.

In April 2014, the OECD announced in a webcast that the country-by-country template will be modified to require reporting of aggregated information by country, rather than requiring entity-based reporting. Further, the template will include a list of all group entities by country, together with the business activity codes for their major activities. Also, it was announced that the columns relating to royalties, interest and service fees received from or paid to associated enterprises will be eliminated. Furthermore, the data used to populate the template will be permitted to be sourced from either statutory accounts or financial statement reporting packages applied consistently from year to year across the group.

Finally, in September 2014, the OECD released its final deliverable on Action $13 .{ }^{75}$ The template format given by the final deliverable report has eliminated the columns relating to royalties, interest and service fees received from or paid to AEs as announced in the webcast. However, the new template has divided the revenue column into revenue derived from related and unrelated parties. The MNE group should report information relevant to the tax jurisdictions in which it operates in the template. Such information should be aggregated information of all constituent entities of the MNE group operating in that jurisdiction. The report has defined tax jurisdiction as the jurisdiction wherein the constituent entities of the MNE group have their place of residence for tax purposes. Further, the constituent entities are defined as incorporated or unincorporated business units of MNE groups (including permanent establishments).

\subsubsection{Can the template be used for a profit split method analysis?}

As mentioned, the profit split method has also not been used extensively due to a lack of financial information of foreign affiliates. However, as the proposed country-bycountry template provides country-by-country financial information of the multinational enterprise, such information could be analysed and form a basis for applying the profit split method. While the OECD has clearly indicated that the country-by-country template should be used as tool only for carrying out high-level transfer pricing risk

74. OECD, Discussion Draft on Transfer Pricing Documentation and CbC Reporting, supra n. 73, at 15 .

75. OECD, Guidance on Transfer Pricing Documentation and Country-byCountry Reporting, supra n. 2. assessments, ${ }^{76}$ it nevertheless needs to be explored whether the country-by-country template itself can be used as an aid or tool for carrying out detailed transfer pricing analysis, in the absence of detailed information of foreign affiliates.

First, if the information in relation to country-by-country revenue and earnings before taxes, as reported in the country-by-country template, matches the revenue and earnings before taxes earned by the parties to the controlled transaction at hand, the profit split method can be applied, as data in respect of the taxpayer and its affiliates may be readily available. Second, tax authorities may use internal information in the country-by-country template (e.g. the number of employees, total employee expense or total book value of tangible assets) as ad hoc allocation keys to attribute profit under a profit split method analysis, in particular the residual profit split mechanism. ${ }^{77}$

On the other hand, there might be situations where tax administrations (as well as taxpayers) may find it difficult to apply the profit split method using the country-bycountry template. First, as the country-by-country template reports only net profit figures and not gross profit figures, the profit split method at a gross profit level may not be possible.

Second, if the country-by-country template were to report aggregated information on multinational enterprise operations in a particular country and such aggregated information also includes data of entities which were not part of the controlled transaction, such country-by-country template may not be useful for testing the arm's length nature of the profit split in the controlled transaction under examination. Further, related-party revenue data may be an aggregation of several controlled transactions (which may or may not be interlinked). Determining the arm's length price using such aggregated information with respect to controlled transactions may not result in a sound transfer pricing analysis. Also profit data in the template are not divided into profit derived from relatedor unrelated-party transactions. Hence, such entity level information may not help to carry out a profit split method analysis of a particular transaction.

Third, another difficulty that can arise when using the country-by-country template to apply the profit split method concerns differences relating to accounting. It is unclear whether the data in respect of revenue and profit compiled in the template would be based on common accounting standards. In order for the data in such template to be comparable, they should be accounted for using some common financial reporting standard, such as the International Financial Reporting Standards (IFRS). In the absence of uniformity in reporting standards in respect

76. OECD, Discussion Draft on Transfer Pricing Documentation and CbC Reporting, supra n. 73, para. 21.

77. As discussed in section 3.2.3., the use of allocation keys depends on the facts and circumstances of each case. It would be inappropriate to use the general information available in the country-by-country template as allocation keys because such keys do not take into consideration the respective value contribution of the parties to the transactions. 
of country-by-country data, the country-by-country template cannot be used to apply the profit split method.

Fourth, use of the employee number from the template as an allocation key for the profit split analysis is impossible due to the definition of an employee. The deliverable report stipulates that the employee data (number of employees) may also include individual independent contractors who participate in the activities of constituent entities of an MNE group in a tax jurisdiction. The independent contractors may not be participants to the controlled transactions of the MNE group and, thus, considering their data for the splitting of profits arising from controlled transactions may not be in line with the arm's length principle.

Finally, although the data in the template will be based on a single reporting currency (which would be the currency of the country where the multinational group's holding company is situated - as it is the holding company which would prepare the template), difficulties may arise with regard to the choice of the conversion rate when converting the data into the currency of the country where the taxpayer is situated for purposes of applying the profit split method. Although such difficulty may be overcome if the average annual conversion rate is applied consistently for currency conversion, questions may still arise regarding the accuracy of the profit split method analysis undertaken.
Given the above-mentioned difficulties, in the authors' opinion the country-by-country template, as such, cannot be used for a profit split method analysis (contribution or comparable or residual profit split). At most, such a template can be used for undertaking a global formulary apportionment. However, given that the arm's length principle is here to stay, the template should not be used for ad hoc allocations. Nonetheless, the country-by-country template may serve as a guiding factor for evaluating and applying the profit split method.

\section{Conclusion}

Today's changing environment increases the importance of a multi-faceted analysis that takes into consideration the value created throughout the supply chain. For years, taxpayers and tax authorities have relied on one-sided methods. However, in light of the BEPS Action Plan, the authors agree with the prediction that two-sided methods will be applied more frequently. The country-by-country template could serve as a useful starting point to ascertain whether a profit split method should be undertaken. If the application of the method is warranted, tax administrations could obtain information from each other by using a plethora of instruments propagated by the OECD and European Union Thus, it is suggested that MNEs already evaluate the implications under a profit split method analysis, as transfer pricing disputes will be on the rise. 